\title{
Low abundance and high species richness: the structure of the soft-bottom isopod fauna of a West Antarctic glacial fjord
}

\author{
Karol Zemko ${ }^{1} \cdot$ Krzysztof Pabis $^{1}$ (D) $\cdot$ Jacek Siciński $^{1} \cdot$ Magdalena Błażewicz $^{1}$
}

Received: 9 June 2016/Revised: 21 February 2017/ Accepted: 9 May 2017/Published online: 1 June 2017

(c) The Author(s) 2017. This article is an open access publication

\begin{abstract}
Isopods belong to the most speciose groups of the Antarctic benthic fauna, although the knowledge on their diversity and small-scale distribution patterns is still limited. Here we analyze the diversity of the isopod fauna in the Admiralty Bay, a glacial fjord on the King George Island. The basin is located in the region of the Antarctic Peninsula, the fastest warming area of the Southern Ocean. The study provides important baseline data for future research, particularly with respect to temporal fluctuations in benthic fauna, associated with global changes observed in that part of the world. Forty species of isopods representing 19 families were recorded on the soft bottom of the Admiralty Bay. The analyses were based on 99 quantitative samples collected, within the 20-502-m depth range, with a $0.1 \mathrm{~m}^{2}$ van Veen grab. The materials for the analyses were obtained in the austral summer seasons of 1984/1985 and $1985 / 1986$. The data revealed a high number of isopod species occurring at a low abundance, the mean abundance amounting to $4.8 \pm 8.6$ ind./ $/ 0.1 \mathrm{~m}^{2}$. Most of the species occurred at low abundances, $25 \%$ of the species being represented by singletons. Caecognathia polaris, the most abundant species, showed the mean abundance of merely $1.2 \pm 4.2$ ind. $/ 0.1 \mathrm{~m}^{2}$. Species richness, diversity and
\end{abstract}

Krzysztof Pabis

cataclysta@wp.pl

Karol Zemko

karolzemko85@gmail.com

Jacek Siciński

sicinski@biol.uni.lodz.pl

Magdalena Błażewicz

magdab@biol.uni.lodz.pl

1 Laboratory of Polar Biology and Oceanobiology, University of Łódź, Banacha 12/16, 90-237 Łódź, Poland abundance of the isopod fauna were much higher in the central basin of the Admiralty Bay than in the Ezcurra Inlet, an area affected by a strong disturbance of glacial origin.

Keywords Admiralty Bay · South Shetland Islands · Peracarida $\cdot$ Diversity $\cdot$ Distribution patterns

\section{Introduction}

Isopods are one of the key groups of benthic macrofauna of the Southern Ocean (De Broyer et al. 2011). They inhabit a great variety of microhabitats, and can be found from the intertidal zone down to the abyssal and hadal depths (Brandt et al. 2007; Kaiser 2014). They are an important component of the Antarctic trophic web and represent a high diversity of feeding modes (Poore and Bruce 2012; Kaiser 2014). Isopods are benthic brooders characterized by a limited dispersal potential, which makes them potentially good indicators of changes associated with various types of natural and anthropogenic disturbance (Veloso et al. 2011; Siciński et al. 2012; Longo et al. 2013). Some species have been shown to be vulnerable to largescale environmental changes observed in the region of the West Antarctic Peninsula (Ingels et al. 2012). Specifically, the mobility, physiology and development of benthic isopods may be affected by modification of hydrological and sedimentary regimes (Young et al. 2006; Janecki et al. 2010).

Following recent focused programmes, the current knowledge on the diversity and zoogeography of isopods in the Southern Ocean is quite comprehensive (e.g. Kussakin 1967; Kussakin 1973; Brandt 1990, 1992; De Broyer et al. 2011; Kaiser 2014), although ecological studies have been 
scarce, most concerning only the shallowest soft-bottom areas (e.g. Lowry 1975; Richardson and Hedgpeth 1977; Siciński et al. 2012; Bick and Arlt 2013). Moreover, no studies have addressed exclusively distribution patterns of the isopod fauna. The areas studied most thoroughly in terms of the Southern Ocean Isopoda species richness are large basins, including the Ross Sea (Choudhury and Brandt 2009), the Weddell Sea (Brandt 1992), the Bellingshausen Sea (Brandt 1999) and the region of the South Shetland Islands (Castello 2004). Some recent studies tackled also the deep-sea isopod fauna from different parts of the Southern Ocean (e.g. Brandt et al. 2007; Kaiser et al. 2007). The lack of a baseline knowledge on the diversity and distribution patterns of isopods at the scale of fjords or small inlets and glacial bays can hamper future analyses of possible climate-change effects on spatial and temporal variability in benthic communities. Fjords, small inlets and glacial bays support habitats that are highly vulnerable to climate-related changes, including increased sedimentation rates, alterations of temperature and salinity or silting of bottom sediments, which substantially affect the benthic fauna (Wlodarska-Kowalczuk and Pearson 2004; Węsławski et al. 2011; Kedra et al. 2013; Pabis et al. 2015). It is therefore critical to establish benchmarks against which the levels of future changes in polar fjords can be assessed. Some long-term changes in the structure of benthic communities have already been observed in the Antarctic (e.g. Pabis and Sobczyk 2015; Moon et al. 2015; Sahade et al. 2015), but there remains a need to develop a system of monitoring sites that will allow comprehensive and meaningful evaluation of global environmental changes in the benthic fauna of the whole region.

The Admiralty Bay is one of the most comprehensively studied small-scale marine basins in the whole Southern Ocean, with about 100 studies focused on diverse groups of macroinvertebrates, including the following: polychaetes (Siciński 2004; Petti et al. 2006; Pabis and Siciński 2010a, b), echinoderms (Presler and Figielska 1997), bryozoans (Nowak et al. 2014; Pabis et al. 2014) and some groups of peracarid crustaceans (Jażdżewski et al. 1991; Jażdżewska 2011). The Bay has therefore been suggested as a good choice for a monitoring site (Siciński et al. 2011). Earlier studies analyzing the isopod fauna of the basin were focused on taxonomy (Teodorczyk and Wägele 1994; Zemko and Brix 2011; Zemko and Kaiser 2012), necrophagous assemblages (Presler 1986), the fauna associated with kelp holdfasts (Zemko et al. 2015) and shallow nearglacial coves (Siciński et al. 2012). In addition, Pabis et al. (2011) analyzed the macroinvertebrate biomass in the Bay. Nevertheless, the knowledge on the ecology of soft-bottom isopod assemblages is still far from complete. Our study aims to analyze distribution patterns and diversity of isopod crustaceans along the full depth range of the Admiralty Bay and in areas characterized by different levels of glacial disturbance.

\section{Materials and methods}

\section{Study area}

The Admiralty Bay is a medium-sized fjord of tectonic origin on the King George Island. It covers an area of about $120 \mathrm{~km}^{2}$. The Bay consists of a central basin and three inner fjords: the Ezcurra Inlet, the Martel Inlet and the MacKellar Inlet. Almost half of the Bay's coastline, especially in the inner fjords (Braun and Grossmann 2002), features glaciers and icefalls. The Admiralty Bay is characterized by a complex set of hydrological properties. It is influenced by warmer and less saline waters from the Bellingshausen Sea and by more saline and colder waters from the Weddell Sea (Tokarczyk 1987). The average tidal range is $1.4 \mathrm{~m}$ (Catewicz and Kowalik 1983), while the exchange of the upper water layer takes about 1-2 weeks (Pruszak 1980).

The Ezcurra Inlet is a narrow fjord with large tidewater glaciers distributed along its coastline. The basin is affected by dynamic glacial processes. A clear gradient of mineral suspension can be observed along the fjord's axis: the highest concentrations of suspended solids $\left(>100 \mathrm{mg} / \mathrm{dm}^{3}\right)$ were recorded in the inner glacial coves, and the lowest concentrations being found in the outer area of the Ezcurra Inlet $\left(15 \mathrm{mg} / \mathrm{dm}^{3}\right)$ and in the central basin $\left(2.8 \mathrm{mg} / \mathrm{dm}^{3}\right)$ (Pecherzewski 1980). In addition, the Ezcurra Inlet shows a high turbidity (Lipski 1987) and a low water chlorophyll a content (Tokarczyk 1986). A submerged sill (about $100 \mathrm{~m}$ high) separates the outer part of the inlet from its middle and inner parts (Marsz 1983). The outermost part of the Ezcurra Inlet features strong currents and exchanges water with the central basin, while the rest of the fjord is characterized by a weak circulation and a lower influence of water from the central basin (Campos et al. 2013). Areas in the vicinity of glaciers show changes in salinity and temperature (Szafranski and Lipski 1982). The central basin and the Martel Inlet are not as strongly influenced by sedimentation processes. The shallowest sublittoral zone down to about $30 \mathrm{~m}$, however, is shaped by growlers and smaller icebergs (Nonato et al. 2000; Pabis et al. 2011). The central basin is the deepest part of the Admiralty Bay (about $550 \mathrm{~m}$ ) and is directly influenced by waters entering from the Bransfield Strait (Siciński et al. 2011).

The nature of bottom sediments is associated with the intensity of glacial processes. The sediments in the inner parts of the Ezcurra Inlet can be described as silty clay and clay silt. The areas of the fjord located farther away from glaciers are characterized by sandy clay silt. The amount of 
skeletal fractions increases along the Inlet's axis too $(\mathrm{Ru}-$ dowski and Marsz 1996; Siciński 2004; Campos et al. 2013). At the same time, the proportion of sand is higher in the central basin, particularly in the shallower sublittoral (Siciński 2004; Siciński et al. 2011).

\section{Sampling}

Samples were collected in the austral summer seasons of $1984 / 1985$ and $1985 / 1986$ with a Van Veen grab $\left(0.1 \mathrm{~m}^{2}\right)$. A total of 99 samples from 99 stations were analyzed. The stations were distributed along the Ezcurra Inlet axis (27 samples, 20-152-depth range) and in the central basin (72 samples, 37-502-m depth range) (Fig. 1). The samples were sieved on $0.5-\mathrm{mm}$ mesh sieves and preserved in $5 \%$ buffered formaldehyde. Subsamples for sediment analysis were collected from part of the material. Grain size data are available for 46 samples (see Siciński 2004). The classification of sediments proposed by Shepard (1954) was used.

\section{Data analysis}

The species richness (S), diversity (Shannon Index, $\log e$ ) and abundance (ind./0.1 $\mathrm{m}^{2}$ ) were calculated for each sample (Magurran 2004). The mean values, standard deviations (SD) and standard errors (SE) of those metrics were calculated for the whole sample set, for the Ezcurra Inlet and for the central basin of the Admiralty Bay. The Mann-Whitney $U$ test was used to test for significance of differences between the Ezcurra Inlet and the central basin of the Admiralty Bay. The deepest station from the Ezcurra Inlet was located at a depth of $152 \mathrm{~m}$. To render the data from the two parts of the Admiralty Bay fully comparable, we also compared the species richness, diversity and abundance using only the data from a similar depth range in the central basin, down to $156 \mathrm{~m}$ (the Ezcurra Inlet: all 27 samples; the central basin: 29 samples). The frequency of occurrence $(F)$, i.e. the percentage of samples containing a species relative to the total number of samples, was calculated for the Ezcurra Inlet, the central basin and the entire sample set.

Species-area accumulation curves, i.e. curves showing the cumulative number of species observed as a new sample was added to the set (Clarke and Warwick 2001), averaged over 999 permutations were plotted using PRIMER 6.0.

\section{Results}

\section{Overall diversity and abundance}

The 99 samples collected, yielding altogether 478 isopod individuals, were found to contain a total of 40 species representing 19 families. Isopods were recorded in 79 samples, and were absent from 20. Most of the isopod-free samples were collected in the Ezcurra Inlet (16 samples, i.e. $60 \%$ of the samples collected in the Inlet). The most speciose families include the Munnidae (seven species) and the Desmosomatidae (five species). The mean abundance of all the species was low. Caecognathia polaris (Hodgson, 1902), the most abundant species overall, occurred at a mean density of only $1.2 \pm 4.2$ ind./0.1 $\mathrm{m}^{2}$ (Table 1). Moreover, ten species (25\%) were singletons, while 12 species $(30 \%)$ were represented by just $2-5$ individuals in the entire material examined. The maximum number of individuals per sample was also low and, for most species, did not exceed 5 ind. $/ 0.1 \mathrm{~m}^{2}$. Only six species occurred at a higher maximum number of individuals per sample (Table 1). The mean total isopod abundance was also low $\left(4.8 \pm 8.6\right.$ ind. $\left./ 0.1 \mathrm{~m}^{2}\right)$, the maximum abundance amounting to 59 ind./0.1 $\mathrm{m}^{2}$. The species accumulation curve did not reach the asymptote (Fig. 2).

\section{The Ezcurra Inlet versus the central basin of the Admiralty Bay}

The Ezcurra Inlet, a shallower and highly disturbed part of the Admiralty Bay, was found to support as few as 13 species, all occurring with extremely low abundances (Table 1). Moreover, the mean total abundance $(1.5 \pm 2.9$ ind. $/ 0.1 \mathrm{~m}^{2}$, Max $=13$ ind. $/ 0.1 \mathrm{~m}^{2}$ ) and frequency of occurrence $(40 \%)$ of isopods were also low. The Inlet supported two species (Ectias turqueti, Richardson. 1906 and Munna jazdzewskii, Teodorczyk and Wägele 1994) not found elsewhere in the Bay.

The isopod fauna diversity in the central basin was much higher than that in the Ezcurra Inlet. The central basin supported 38 species. Comparisons carried out for the samples obtained from a depth range identical with that sampled in the Ezcurra Inlet (29 samples collected down to $156 \mathrm{~m}$ depth) showed, however, the number of species in the central basin to be also relatively low (19; Table 1). Mean abundances of two species only, Caecognathia polaris (Hodgson, 1902) (3.8 \pm 7.0 ind./0.1 $\left.\mathrm{m}^{2}\right)$ and Notopais quadrispinosa (Beddard, 1886) (1.3 \pm 1.9 ind./ $0.1 \mathrm{~m}^{2}$ ), exceeded 1 individual per $0.1 \mathrm{~m}^{2}$ in the central basin samples collected to the depth of $156 \mathrm{~m}$ (Table 1).

Our study revealed no general pattern of abundance or the number of species per sample along the depth and sediment gradient of the Ezcurra Inlet and the central basin. The highest values of abundance and the species richness per sample were recorded, however, only in samples retrieved from shallower depths (down to about $50 \mathrm{~m}$ ) in the two parts of the Admiralty Bay studied (Figs. 3, 4). The mean isopod abundance, number of species per sample and diversity (Shannon Index) were higher in the central basin than in the Ezcurra Inlet (Fig. 5), the differences being 


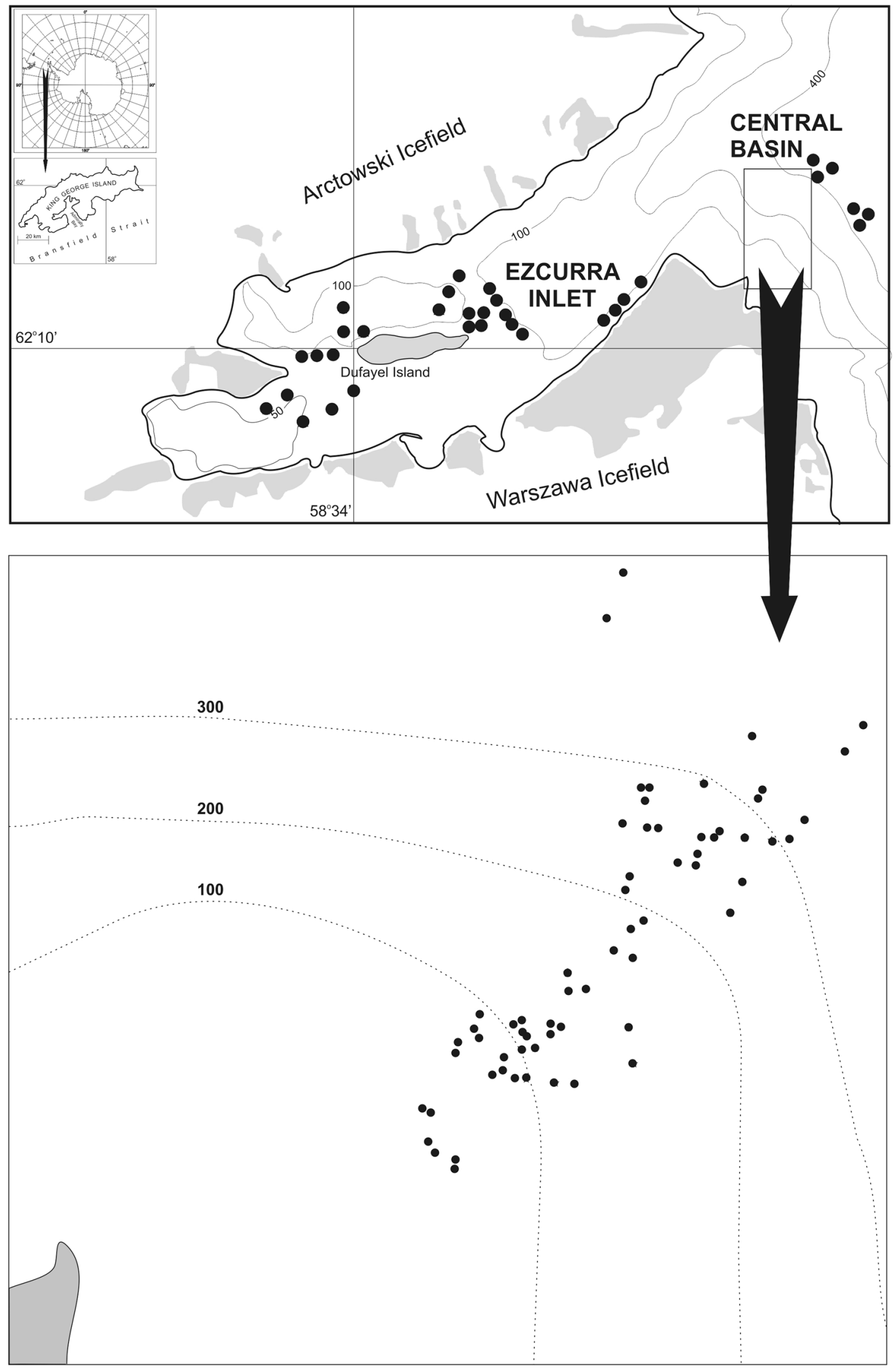

Fig. 1 Distribution of sampling stations in the Admiralty Bay. Samples from the central basin are presented separately 
Table 1 Mean density (ind./0.1 $\mathrm{m}^{2}$ ) with standard deviation (SD), frequency of occurrence (\%) and depth range of isopod species recorded in the studied material

\begin{tabular}{|c|c|c|c|c|c|c|c|c|c|c|}
\hline \multirow[t]{2}{*}{ Species/Family } & \multicolumn{2}{|l|}{ Ezcurra Inlet } & \multicolumn{2}{|l|}{$\begin{array}{l}\text { Central basin } \\
(156 \mathrm{~m})\end{array}$} & \multicolumn{2}{|l|}{ Central basin } & \multicolumn{3}{|l|}{ Total } & \multirow[t]{2}{*}{$\begin{array}{l}\text { Depth } \\
\text { range }\end{array}$} \\
\hline & $\begin{array}{l}\text { Mean } \pm \text { SD } \\
\text { (ind. } / 0.1 \mathrm{~m}^{2} \text { ) }\end{array}$ & $F(\%)$ & $\begin{array}{l}\text { Mean } \pm \mathrm{SD} \\
\text { (ind./0.1 } \mathrm{m}^{2} \text { ) }\end{array}$ & $F(\%)$ & $\begin{array}{l}\text { Mean } \pm \mathrm{SD} \\
\text { (ind. } / 0.1 \mathrm{~m}^{2} \text { ) }\end{array}$ & $F(\%)$ & $\begin{array}{l}\text { Mean } \pm \mathrm{SD} \\
\text { (ind. } / 0.1 \mathrm{~m}^{2} \text { ) }\end{array}$ & $\begin{array}{l}\text { Max } \\
\text { (ind./ } \\
0.1 \mathrm{~m}^{2} \text { ) }\end{array}$ & $F(\%)$ & \\
\hline \multicolumn{11}{|l|}{ Acanthaspidiidae } \\
\hline $\begin{array}{l}\text { Ianthopsis nasicornis } \\
\text { Vanhöffen, (1914) }\end{array}$ & - & - & $0.06 \pm 0.2$ & 6 & $0.04 \pm 0.2$ & 4 & $0.03 \pm 0.1$ & 1 & 3 & $50-400 \mathrm{~m}$ \\
\hline \multicolumn{11}{|l|}{ Antarcturidae } \\
\hline \multicolumn{10}{|l|}{ Chaetiliidae } & $\underline{59-72 \mathrm{~m}}$ \\
\hline $\begin{array}{l}\text { Glyptonotus } \mathrm{cf} \\
\text { antarcticus Eights, } \\
(1852)\end{array}$ & $0.03 \pm 0.1$ & 4 & $0.2 \pm 0.6$ & 13 & $0.08 \pm 0.4$ & 5 & $0.07 \pm 0.3$ & 3 & 5 & $\underline{46-88 \mathrm{~m}}$ \\
\hline \multicolumn{11}{|l|}{ Cirolanidae } \\
\hline $\begin{array}{l}\text { Natatolana oculata } \\
\text { Vanhöffen, (1914) }\end{array}$ & - & - & $0.06 \pm 0.3$ & 3 & $0.05 \pm 0.2$ & 4 & $0.04 \pm 0.2$ & 2 & 3 & 70-280 m \\
\hline $\begin{array}{l}\text { Natatolana } \\
\quad \text { intermedia } \\
\text { Vanhöffen, } 1914\end{array}$ & - & - & - & - & $0.3 \pm 0.7$ & 18 & $0.2 \pm 0.6$ & 4 & 13 & $178-405 \mathrm{~m}$ \\
\hline \multicolumn{11}{|l|}{ Dendrotionidae } \\
\hline Dendrotion sp. & - & - & - & - & $0.01 \pm 0.1$ & 1 & $0.01 \pm 0.1$ & 1 & 1 & $380 \mathrm{~m}$ \\
\hline \multicolumn{11}{|l|}{ Desmosomatidae } \\
\hline $\begin{array}{l}\text { Desmosoma brevipes } \\
\text { Nordenstam, } 1933\end{array}$ & - & - & - & - & $0.01 \pm 0.1$ & 1 & $0.01 \pm 0.1$ & 1 & 1 & $296 \mathrm{~m}$ \\
\hline $\begin{array}{l}\text { Desmosomatidae } \\
\text { gen, sp, }\end{array}$ & $0.07 \pm 0.2$ & 7 & - & - & $0.02 \pm 0.16$ & 3 & $0.04 \pm 0.1$ & 1 & 4 & 48-256 m \\
\hline $\begin{array}{l}\text { Eugerdella cellata } \\
\text { Zemko \& Brix } \\
\text { (2011) }\end{array}$ & - & - & - & - & $0.05 \pm 0.3$ & 3 & $0.04 \pm 0.3$ & 3 & 2 & 296-380 m \\
\hline $\begin{array}{l}\text { Eugerdella } \\
\quad \text { margaretae Zemko } \\
\text { \& Brix (2011) }\end{array}$ & - & - & - & - & $0.01 \pm 0.1$ & 1 & $0.01 \pm 0.1$ & 1 & 1 & $330 \mathrm{~m}$ \\
\hline Prochelator sp. & - & - & - & - & $0.01 \pm 0.1$ & 1 & $0.01 \pm 0.1$ & 1 & 1 & $252 \mathrm{~m}$ \\
\hline Gnathiidae & & & & & & & & & & \\
\hline $\begin{array}{l}\text { Caecognathia calva } \\
\text { Vanhöffen, (1914) }\end{array}$ & - & - & - & - & $0.04 \pm 0.2$ & 3 & $0.03 \pm 0.2$ & 2 & 2 & $256-278 \mathrm{~m}$ \\
\hline $\begin{array}{l}\text { Caecognathia polaris } \\
\text { Hodgson, (1902) }\end{array}$ & $0.07 \pm 0.2$ & 7 & $3.8 \pm 7.0$ & 62 & $1.6 \pm 4.8$ & 26 & $1.2 \pm 4.2$ & 33 & 21 & 39-252 m \\
\hline Caecognathia sp. & $0.1 \pm 0.3$ & 11 & $0.2 \pm 0.5$ & 13 & $0.3 \pm 0.6$ & 22 & $0.2 \pm 0.5$ & 3 & 19 & 45-337 m \\
\hline \multicolumn{11}{|l|}{ Haploniscidae } \\
\hline $\begin{array}{l}\text { Antennuloniscus } \\
\text { armatus Menzies, } \\
1962\end{array}$ & - & - & - & - & $0.1 \pm 0.5$ & 5 & $0.09 \pm 0.4$ & 3 & 4 & $330-405 \mathrm{~m}$ \\
\hline \multicolumn{11}{|l|}{ Idoteidae } \\
\hline \multicolumn{2}{|l|}{ Ischnomesidae } & - & $0.1 \pm 0.3$ & 13 & $0.5 \pm 1.9$ & 15 & $0.3 \pm 1.7$ & 12 & 11 & 55-502 m \\
\hline Ischnomesus sp. & - & - & - & - & $0.01 \pm 0.1$ & 1 & $0.01 \pm 0.1$ & 1 & 1 & $352 \mathrm{~m}$ \\
\hline \multicolumn{11}{|l|}{ Janiridae } \\
\hline $\begin{array}{l}\text { Austrofilius furcatus } \\
\text { Hodgson(1910) }\end{array}$ & $0.2 \pm 1.3$ & 7 & $0.5 \pm 1.9$ & 13 & $0.3 \pm 1.2$ & 14 & $0.3 \pm 1.2$ & 10 & 12 & 45-380 m \\
\hline $\begin{array}{l}\text { Ectias turqueti } \\
\text { Richardson, (1906) }\end{array}$ & $0.07 \pm 0.3$ & 4 & - & - & - & - & $0.02 \pm 0.2$ & 2 & 1 & $\underline{90 \mathrm{~m}}$ \\
\hline
\end{tabular}


Table 1 continued

\begin{tabular}{|c|c|c|c|c|c|c|c|c|c|c|}
\hline \multirow[t]{2}{*}{ Species/Family } & \multicolumn{2}{|l|}{ Ezcurra Inlet } & \multicolumn{2}{|l|}{$\begin{array}{l}\text { Central basin } \\
(156 \mathrm{~m})\end{array}$} & \multicolumn{2}{|l|}{ Central basin } & \multicolumn{3}{|l|}{ Total } & \multirow[t]{2}{*}{$\begin{array}{l}\text { Depth } \\
\text { range }\end{array}$} \\
\hline & $\begin{array}{l}\text { Mean } \pm \mathrm{SD} \\
\text { (ind. } / 0.1 \mathrm{~m}^{2} \text { ) }\end{array}$ & $F(\%)$ & $\begin{array}{l}\text { Mean } \pm \mathrm{SD} \\
\text { (ind. } / 0.1 \mathrm{~m}^{2} \text { ) }\end{array}$ & $F(\%)$ & $\begin{array}{l}\text { Mean } \pm \mathrm{SD} \\
\text { (ind. } / 0.1 \mathrm{~m}^{2} \text { ) }\end{array}$ & $F(\%)$ & $\begin{array}{l}\text { Mean } \pm \mathrm{SD} \\
\text { (ind. } / 0.1 \mathrm{~m}^{2} \text { ) }\end{array}$ & $\begin{array}{l}\text { Max } \\
\text { (ind./ } \\
0.1 \mathrm{~m}^{2} \text { ) }\end{array}$ & $F(\%)$ & \\
\hline $\begin{array}{l}\text { Iathrippa sarsi } \\
\text { Pfeffer, (1887) }\end{array}$ & - & - & $0.2 \pm 0.9$ & 10 & $0.1 \pm 0.5$ & 4 & $0.08 \pm 0.5$ & 4 & 3 & 39-53 m \\
\hline \multicolumn{11}{|l|}{ Joeropsididae } \\
\hline $\begin{array}{l}\text { Joeropsis } \\
\quad \text { intermedius } \\
\quad \text { Nordenstam, } 1933\end{array}$ & - & - & $0.4 \pm 0.8$ & 27 & $0.3 \pm 0.7$ & 18 & $0.2 \pm 0.6$ & 3 & 13 & 46-330 m \\
\hline \multicolumn{11}{|l|}{ Leptanthuridae } \\
\hline $\begin{array}{l}\text { Accalathura } \\
\text { gigantissima Poore, } \\
1981\end{array}$ & - & - & - & - & $0.01 \pm 0.1$ & 1 & $0.01 \pm 0.1$ & 1 & 1 & $290 \mathrm{~m}$ \\
\hline $\begin{array}{l}\text { Leptanthura glacialis } \\
\text { Hodgson (1910) }\end{array}$ & - & - & - & - & $0.1 \pm 0.4$ & 10 & $0.1 \pm 0.3$ & 2 & 7 & $212-335 \mathrm{~m}$ \\
\hline \multicolumn{11}{|l|}{ Munnidae } \\
\hline $\begin{array}{l}\text { Munna antarctica } \\
\text { Pfeffer, (1887) }\end{array}$ & - & - & $0.4 \pm 1.0$ & 24 & $0.1 \pm 0.7$ & 10 & $0.1 \pm 0.6$ & 4 & 7 & 50-156 m \\
\hline $\begin{array}{r}\text { Munna globicauda } \\
\text { Vanhöffen, } 1914\end{array}$ & - & - & - & - & $0.06 \pm 0.3$ & 4 & $0.05 \pm 0.2$ & 2 & 3 & $175-278 \mathrm{~m}$ \\
\hline $\begin{array}{l}\text { Munna jazdzewskii } \\
\text { Teodorczyk \& } \\
\text { Wägele, (1994) }\end{array}$ & $0.2 \pm 0.9$ & 7 & - & - & - & - & $0.06 \pm 0.5$ & 5 & 2 & $\underline{20-26 \mathrm{~m}}$ \\
\hline $\begin{array}{c}\text { Munna longipoda } \\
\text { Teodorczyk \& } \\
\text { Wägele, (1994) }\end{array}$ & $0.03 \pm 0.1$ & 4 & $0.3 \pm 1.4$ & 6 & $0.1 \pm 0.9$ & 3 & $0.1 \pm 0.8$ & 8 & 3 & $\underline{48-72 \mathrm{~m}}$ \\
\hline $\begin{array}{l}\text { Munna neglecta } \\
\text { Monod, (1931) }\end{array}$ & - & - & $0.03 \pm 0.1$ & 3 & $0.01 \pm 0.1$ & 1 & $0.01 \pm 0.1$ & 1 & 1 & $\underline{39 \mathrm{~m}}$ \\
\hline $\begin{array}{l}\text { Munna pallida } \\
\text { Beddard, (1886) }\end{array}$ & - & - & - & - & $0.02 \pm 0.1$ & 3 & $0.02 \pm 0.1$ & 1 & 2 & $162-278 \mathrm{~m}$ \\
\hline $\begin{array}{l}\text { Munna spicata } \\
\text { Teodorczyk \& } \\
\text { Wägele, (1994) }\end{array}$ & - & - & - & - & $0.06 \pm 0.3$ & 5 & $0.05 \pm 0.2$ & 2 & 4 & 240-330 m \\
\hline \multicolumn{11}{|l|}{ Munnopsidae } \\
\hline $\begin{array}{l}\text { Coperonus frigida } \\
\text { Vanhöffen, (1914) }\end{array}$ & - & - & - & - & $0.01 \pm 0.1$ & 1 & $0.01 \pm 0.1$ & 1 & 1 & $240 \mathrm{~m}$ \\
\hline $\begin{array}{l}\text { Ilyarachna } \\
\text { antarctica } \\
\text { Vanhöffen, (1914) }\end{array}$ & $0.2 \pm 0.6$ & 11 & $0.5 \pm 2.5$ & 6 & $0.2 \pm 1.6$ & 4 & $0.2 \pm 1.4$ & 14 & 6 & 45-206 m \\
\hline $\begin{array}{l}\text { Notopais } \\
\text { quadrispinosa } \\
\text { Beddard,(1886) }\end{array}$ & $0.1 \pm 0.6$ & 11 & $1.3 \pm 1.9$ & 58 & $0.7 \pm 1.4$ & 35 & $0.5 \pm 1.2$ & 9 & 28 & 45-335 m \\
\hline \multicolumn{11}{|l|}{ Paramunnidae } \\
\hline $\begin{array}{l}\text { Austrosignum } \\
\text { glaciale } \\
\text { Hodgson(1910) }\end{array}$ & $0.07 \pm 0.3$ & 4 & $0.1 \pm 0.4$ & 10 & $0.05 \pm 0.2$ & 4 & $0.06 \pm 0.3$ & 2 & 4 & $\underline{26-60 \mathrm{~m}}$ \\
\hline $\begin{array}{l}\text { Pagonana rostrata } \\
\text { Hodgson (1910) }\end{array}$ & $0.07 \pm 0.2$ & 7 & $0.03 \pm 0.1$ & 3 & $0.02 \pm 0.1$ & 3 & $0.04 \pm 0.1$ & 1 & 4 & 45-380 m \\
\hline $\begin{array}{l}\text { Pleurosignum cf } \\
\text { chilense Menzies, } \\
\text { (1962) }\end{array}$ & - & - & - & - & $0.01 \pm 0.1$ & 1 & $0.01 \pm 0.1$ & 1 & 1 & $496 \mathrm{~m}$ \\
\hline \multicolumn{11}{|l|}{ Santiidae } \\
\hline $\begin{array}{l}\text { Santia mawsoni } \\
\text { Hale, (1937) }\end{array}$ & - & - & $0.2 \pm 0.7$ & 17 & $0.1 \pm 0.4$ & 7 & $0.08 \pm 0.3$ & 3 & 5 & $46-156 \mathrm{~m}$ \\
\hline
\end{tabular}


Table 1 continued

\begin{tabular}{|c|c|c|c|c|c|c|c|c|c|c|}
\hline \multirow[t]{2}{*}{ Species/Family } & \multicolumn{2}{|l|}{ Ezcurra Inlet } & \multicolumn{2}{|l|}{$\begin{array}{l}\text { Central basin } \\
(156 \mathrm{~m})\end{array}$} & \multicolumn{2}{|l|}{ Central basin } & \multicolumn{3}{|l|}{ Total } & \multirow[t]{2}{*}{$\begin{array}{l}\text { Depth } \\
\text { range }\end{array}$} \\
\hline & $\begin{array}{l}\text { Mean } \pm \mathrm{SD} \\
\text { (ind. } / 0.1 \mathrm{~m}^{2} \text { ) }\end{array}$ & $F(\%)$ & $\begin{array}{l}\text { Mean } \pm \mathrm{SD} \\
\text { (ind. } / 0.1 \mathrm{~m}^{2} \text { ) }\end{array}$ & $F(\%)$ & $\begin{array}{l}\text { Mean } \pm \mathrm{SD} \\
\text { (ind. } / 0.1 \mathrm{~m}^{2} \text { ) }\end{array}$ & $F(\%)$ & $\begin{array}{l}\text { Mean } \pm \mathrm{SD} \\
\text { (ind. } / 0.1 \mathrm{~m}^{2} \text { ) }\end{array}$ & $\begin{array}{l}\text { Max } \\
\text { (ind./ } \\
0.1 \mathrm{~m}^{2} \text { ) }\end{array}$ & $F(\%)$ & \\
\hline \multicolumn{11}{|l|}{ Serolidae } \\
\hline $\begin{array}{l}\text { Paraserolis polita } \\
\text { Pfeffer, (1887) }\end{array}$ & - & - & $0.1 \pm 0.5$ & 10 & $0.08 \pm 0.3$ & 5 & $0.06 \pm 0.3$ & 2 & 4 & 37-333 m \\
\hline $\begin{array}{l}\text { Serolella bouvieri } \\
\quad \text { Richardson, (1906) }\end{array}$ & - & - & - & - & $0.01 \pm 0.1$ & 1 & $0.01 \pm 0.1$ & 1 & 1 & $405 \mathrm{~m}$ \\
\hline \multicolumn{11}{|l|}{ Thambematidae } \\
\hline $\begin{array}{l}\text { Thambema } \\
\text { thunderstruckae } \\
\text { Zemko \& Kaiser } \\
\text { (2012) }\end{array}$ & $0.07 \pm 0.2$ & 7 & - & - & $0.02 \pm 0.2$ & 1 & $0.04 \pm 0.2$ & 2 & 3 & 45-212 m \\
\hline
\end{tabular}

The bathymetric ranges of species (last column) occurring along the wider depth range of the Admiralty Bay are marked in bold; species recorded only in shallower sublittoral are underline, while the species recorded in the deeper sublittoral are given in normal font

Fig. 2 Species-area accumulation curve averaged over 999 permutations (cumulative number of different isopod species observed as each new sample was added)

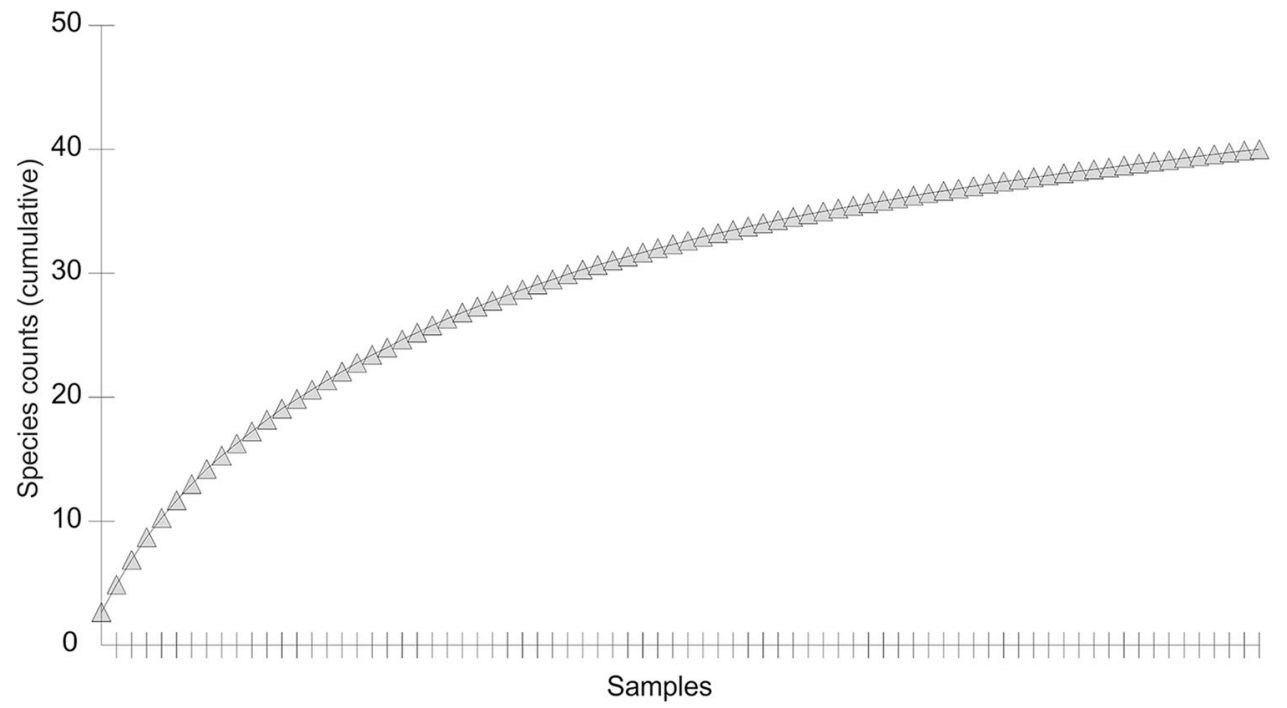

significant in each case (Mann-Whitney $U$ test, $p<0.0001, p<0.0001, p=0.002$, respectively). The differences were even more apparent in the analysis of samples collected down to $156 \mathrm{~m}$ (the maximum depth of the sampling stations in the Ezcurra Inlet) (Fig. 5) and were significant in all the three metrics (Mann-Whitney $U$ test, $p<0.0001)$.

\section{Bathymetric distribution of species}

Analysis of the bathymetric distribution of the isopod species identified in the Admiralty Bay allowed to distinguish three groups. Eight species were recorded only in the shallow sublittoral, down to about 90-m depth. The second group contained 14 species occurring along a wider depth range; they were found in the shallow sublittoral, but also at the deepest stations of the central basin. The largest group consisted of the species recorded in the deeper areas, below a depth of about $200 \mathrm{~m}$ (Table 1).

\section{Discussion}

Benthic macroinvertebrates of the Admiralty Bay show a high species richness. So far, a total of 99 species of isopod crustaceans have been recorded in the basin (Arnaud et al. 1986; Presler 1986; Teodorczyk and Wagele 1994; Zemko and Kaiser 2012; Siciński et al. 2012; Zemko et al. 2015; Zemko unpublished results). Isopods are the third most speciose macrofaunal group in the Admiralty Bay, 
Fig. 3 Number of isopod species per sample and their abundances (ind./ $/ 0.1 \mathrm{~m}^{2}$ ) along a depth gradient of the Admiralty Bay central basin. Per cent contributions of sand, silt and clay are indicated as well (classification of sediments proposed by Shepard (1954))
Fig. 4 Number of isopod species per sample and their abundances (ind./0.1 $\mathrm{m}^{2}$ ) along a depth gradient of the Ezcurra Inlet. Per cent contributions of sand, silt and clay are indicated as well (classification of sediments proposed by Shepard (1954))
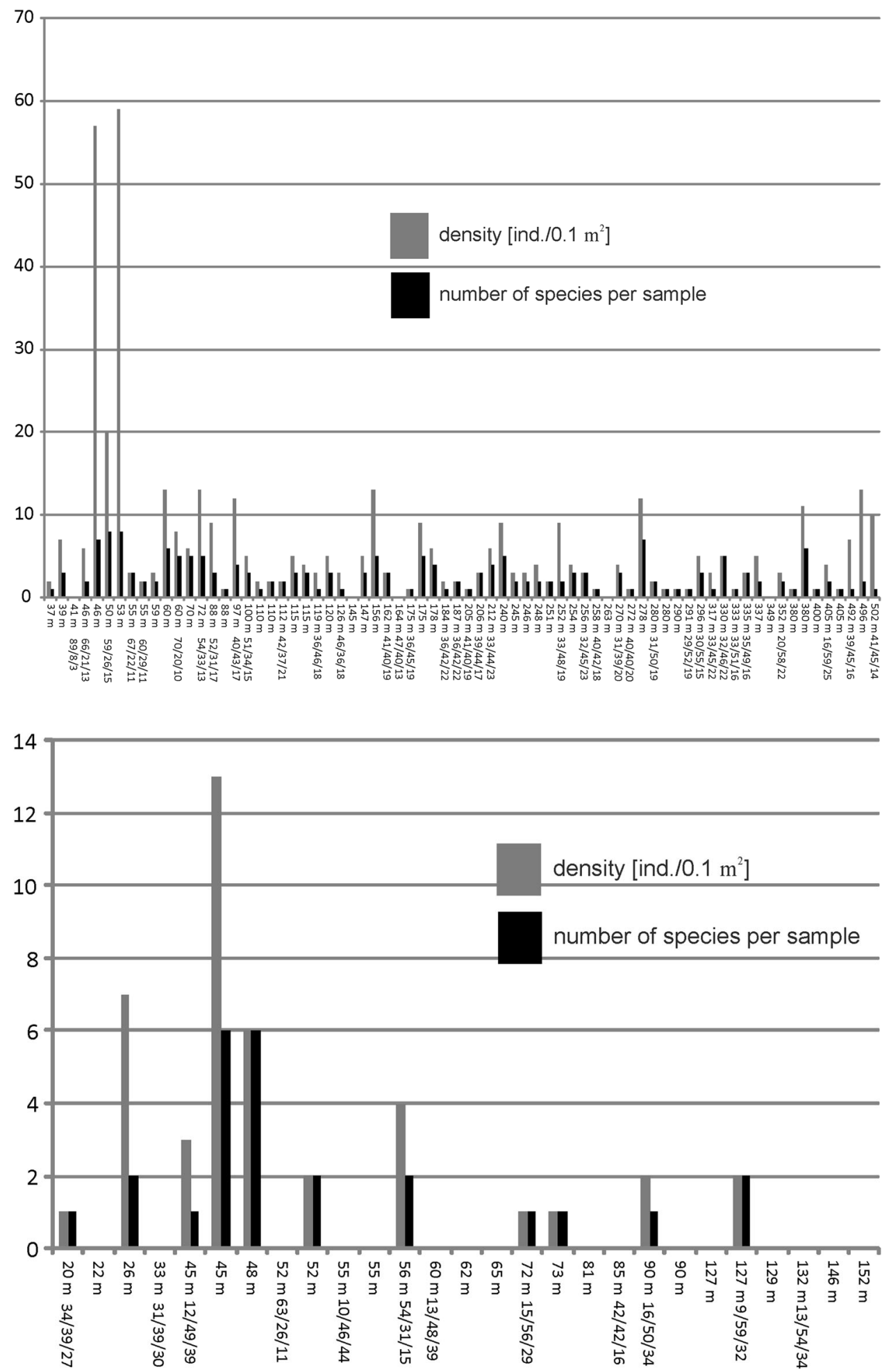

following the Amphipoda (172 species) and Polychaeta (162 species) (Siciński et al. 2011). This small (surface area of $120 \mathrm{~km}^{2}$ ) basin hosts about $23 \%$ of all the isopod species described from the Southern Ocean (DeBroyer et al. 2011) and about $64 \%$ of isopods found off the South Shetland Islands (Castello 2004), although those proportions will certainly change once new species from the deep sea are described (Brandt et al. 2007). The high diversity of the Bay's isopods might be associated with a multitude of various microhabitats in the basin (Sicinski et al. 2011), and also with the zoogeographic location of the South Shetlands. The region shows affinity to the 

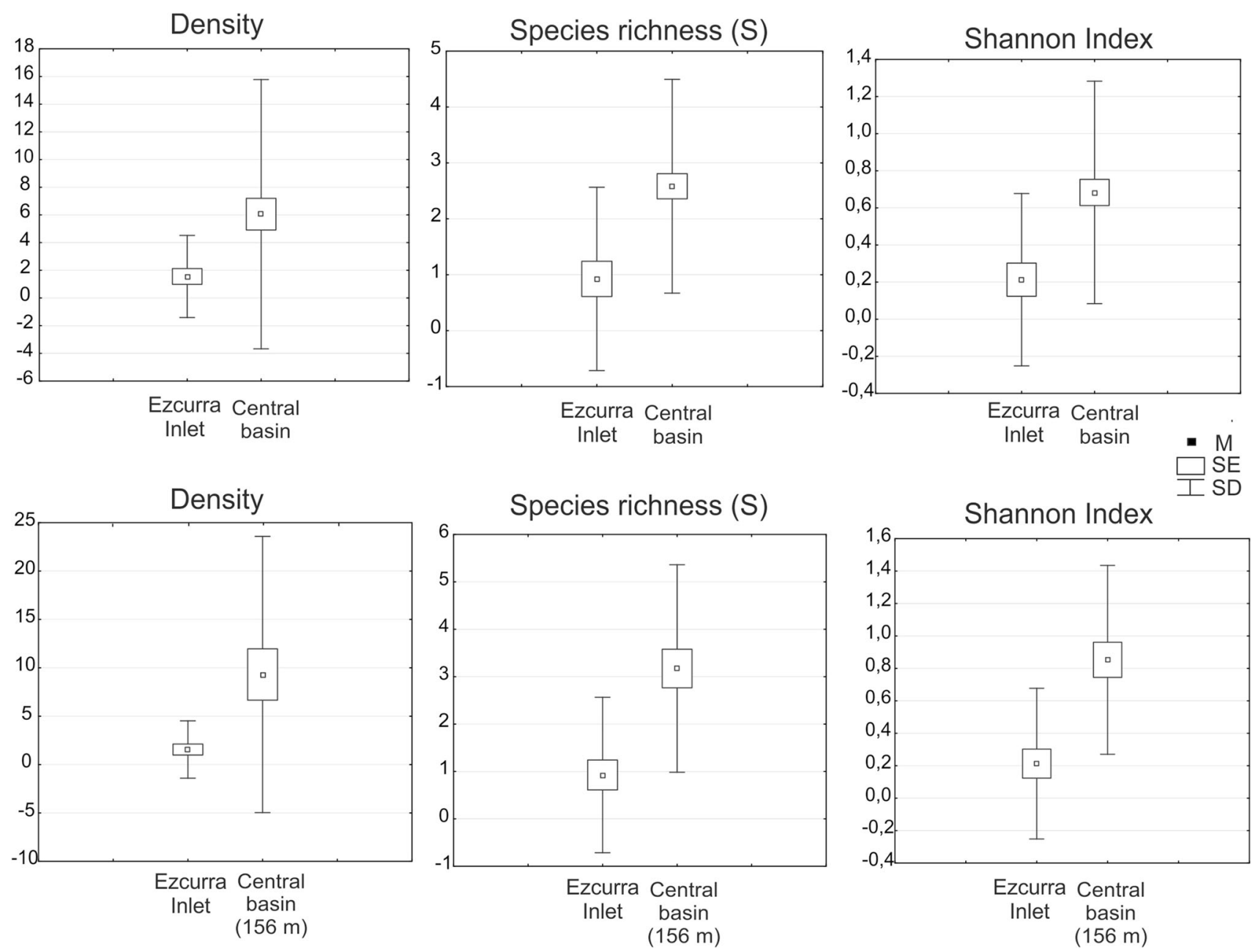

Fig. 5 Comparison of isopod species richness (S), diversity (Shannon Index) and abundance between the Ezcurra Inlet and the central basin of the Admiralty Bay. $M$ mean, $S D$ standard deviation, $S E$ standard

Magellan area and the Scotia Arc (De Broyer and Koubbi 2014). Moreover, the Bransfield Strait may have been a glacial refuge for benthic fauna during the last glacial maximum (Anderson et al. 2002). On the other hand, the Admiralty Bay is a small area that was intensively sampled during the last 35 years. This could have also accounted for the list of taxa being more comprehensive than elsewhere (see also Siciński et al. 2011). In a similar basin (Arthur Harbour, Anvers Island), 69 samples yielded as few as 39 isopod species. Substantial differences in the isopod species richness have also been revealed between Arctic and Antarctic polar fjords. Generally, the number of isopod species recorded in the Antarctic (441) (De Broyer et al. 2011) is higher than that in the Arctic (112 species) (Piepenburg et al. 2011). There, small-scale differences (between areas showing similar habitat characteristics in single glacial inlets) have been observed. Only two isopod species were recorded in the Spitsbergen fjord Hornsund (Kedra et al. 2010). On the other hand, other groups, e.g. error. Data from the central basin concern the entire material as well as samples collected down to $156-\mathrm{m}$ depth, i.e. the maximum depth sampled in the Ezcurra Inlet

polychaetes or amphipods, show no such high differences between the Hornsund and the Admiralty Bay (Kedra et al. 2010; Siciński et al. 2011; Pabis et al. 2015).

On the soft bottom of the Admiralty Bay, isopods occurred with a high species richness, but their abundances were low. Abundances of polychates and amphipods in the basin are much higher than the isopod abundance (Siciński 2004; Jażdżewska 2011). Comparable or higher abundances, at least in some areas of Admiralty Bay, including the Ezcurra Inlet, have been observed in much less diverse soft-bottom peracarids such as the Cumacea (15 species) and Tanaidacea (14 species) (Błażewicz-Paszkowycz and Jażdżewski 2000; Błażewicz-Paszkowycz and SekulskaNalewajko 2004; Pabis and Błażewicz-Paszkowycz 2011).

The Southern Ocean isopod fauna has been studied primarily on qualitative samples collected with dredges or an epibenthic sledge, the major focus being on species richness assessment, zoogeography or deep-sea communities (e.g. Brandt et al. 2004, 2005; Kaiser et al. 2007; Choudhury and 
Brandt 2009). The abundance of isopods in other small coves and bays in the Antarctic Peninsula region was found to be low, although direct comparisons with our data are problematic. For example, information on the 39 isopod species recorded in the Arthur Harbour is not accompanied by data on their abundance, except for a brief statement that the abundances were low (Richardson and Hedgpeth 1977).

The much lower abundance and diversity of the isopod fauna in the Ezcurra Inlet, compared to the central basin of the Admiralty Bay, can be quite easily explained by the differences in the hydrological and sedimentary regimes (Pecherzewski 1980; Szafranski and Lipski 1982; Rudowski and Marsz 1996; Siciński 2004; Campos et al. 2013). Glacial fjord fauna is generally impoverished in terms of biodiversity and abundance on account of various types of disturbance, such as increased mineral sedimentation and silting of bottom deposits (Włodarska-Kowalczuk and Pearson 2004; Siciński et al. 2011; Kędra et al. 2013). Generally, a gradual increase in macrofaunal abundance and diversity is observed along the polar fjord axis, and is accompanied by changes in species composition (Siciński 2004; Włodarska-Kowalczuk and Pearson 2004; Kedra et al. 2013).

The isopod fauna of the Admiralty Bay does not form distinct faunal assemblages associated with specific depth zones or different sediment types. Although some species were recorded only in the shallower sublittoral and other occurred only in the deepest bottom areas of the Admiralty Bay (Table 1), most of those species were singletons or doubletons. Therefore, we cannot speculate about the strength of this pattern in the Admiralty Bay. Moreover, many of the species recorded in our study have been shown to occur over wider depth ranges at other Antarctic sites (e.g. Hodgson 1910; Castello 2004; Choudhury and Brandt 2009), although bathymetric distribution of a species may differ between semi-closed basins such as the Admiralty Bay and open shelf sites. On the other hand, polychaetes and amphipods showed a clear depth zonation in the Admiralty Bay (Siciński 2004; Pabis and Siciński 2010b, 2012; Jażdżewska and Siciński 2017).

Our study was based on a large set of quantitative samples. As the species-area cumulative curve was quite steep, the Admiralty Bay may be expected to support still more isopod species. A higher sampling effort and a larger number of replicates would be necessary to improve the knowledge on the patchiness level in isopod distribution. These conclusions are supported by data from a small area of the Ezcurra Inlet neighbouring the Herve Cove, a glacial bay, where some isopod species (e.g. Munna jazdzewskii $30.8 \pm 56.2$ ind. $/ 0.1 \mathrm{~m}^{2}$ ) occurred with high mean abundances (Siciński et al. 2012) or by our results showing a low mean abundance of Caecognathia polaris, but a high maximum number of individuals in a single sample (Table 1).
Isopods were absent in more than a half of the samples collected in the glacially affected Ezcurra Inlet, and their abundance in the remaining samples from the area was very low (Fig. 4). This might suggest that, generally, isopods are more sensitive to glacial disturbance than other peracarid crustaceans such as the Tanaidacea, Cumacea or Amphipoda, which were more abundant in this glacial inlet, especially in its central and outer part (Błażewicz-Paszkowycz and Jażdżewski 2000; Jażdżewska 2011; Pabis and BłażewiczPaszkowycz 2011; Jażdżewska and Siciński 2017).

Further studies on the isopod fauna in glacial fjords should focus on the assessment of patchiness level, which will require a higher sampling effort and a more extensive and uniform distribution of sampling stations, particularly in heavily disturbed areas such as the Ezcurra Inlet. The ongoing changes associated with the climate warming in the Antarctic Peninsula region (Walsh 2009) might also affect isopod assemblages, as they are sensitive to glacial disturbance. If the level of isopod rarity in glacial Antarctic inlets is really as high as that shown by our data, local populations of some species may become extinct in smaller isolated basins directly due to changes in environmental conditions, as shown in scenarios proposed by Ingels et al. (2012). Our analysis was based on samples collected 30 years ago and thus can be used as a baseline for further studies, especially those investigating long-term changes in composition and diversity of the benthic fauna. Problems associated with distribution and diversity of the Southern Ocean isopod fauna (its rarity and patchiness in particular) on a microhabitat scale certainly deserve more attention in future research programmes.

Acknowledgements The study was supported by a Grant of the Polish Ministry of Science and Higher Education No 51/N-IPY/2007/ 0 as well as by the Census of Antarctic Marine Life project. Karol Zemko and Krzysztof Pabis were also supported by University of Lodz internal funds. We want to thank the reviewers for their valuable comments that helped to improve the manuscript. Thanks are also due to Teresa Radziejewska who kindly corrected language through the manuscript.

Open Access This article is distributed under the terms of the Creative Commons Attribution 4.0 International License (http://crea tivecommons.org/licenses/by/4.0/), which permits unrestricted use, distribution, and reproduction in any medium, provided you give appropriate credit to the original author(s) and the source, provide a link to the Creative Commons license, and indicate if changes were made.

\section{References}

Anderson JB, Shipp SS, Lowe AL, Wellner JS, Masola AB (2002) The Antarctic ice sheet during the last glacial maximum and its subsequent retreat history: a review. Quat Sci Rev 21:49-70. doi:10.1016/S0277-3791(01)00083-X

Arnaud PM, Jażdżewski K, Presler P, Siciński J (1986) Preliminary survey of benthic invertebrates collected by polish antarctic 
expeditions in admiralty bay (King George Island, South Shetland Islands, Antarctica). Pol Polar Res 7:7-24

Bick A, Arlt G (2013) Description of intertidal macro- and meiobenthic assemblages in Maxwell Bay, King George Island, South Shetland Islands, Southern Ocean. Polar Biol 36:673-689. doi:10.1007/s00300-013-1293-9

Błażewicz-Paszkowycz M, Jażdżewski K (2000) Quantitative data on Tanaidacea of Admiralty Bay (King George Island, South Shetlands, Antarctic). Pol Polar Res 21:171-180

Błażewicz-Paszkowycz M, Sekulska-Nalewajko J (2004) Tanaidacea (Crustacea, Malacostraca) of two polar fjords: Kongsfjorden (Arctic) and Admiralty Bay (Antarctic). Polar Biol 27:222-230. doi:10.1007/s00300-003-0585-x

Brandt A (1990) Antarctic valviferans (Crustacea, Isopoda, Valvifera). In: Brill EJ (ed) New genera, new species and redescriptions. Kobenhavn- Koln, New York

Brandt A (1992) Origin of Antarctic Isopoda (Crustacea, Malacostraca). Mar Biol 113:415-423

Brandt A (1999) On the origin and the evolution of Antarctic Peracarida (Crustacea, Malacostraca). Sci Mar 63:261-274

Brandt A, Brokeland W, Brix S, Malyutina M (2004) Diversity of southern ocean deep-sea Isopoda (Crustacea, Malacostraca) - a comparison with shelf data. Deep-Sea Res Pt II 51:1753-1768. doi:10.1016/j.dsr2.2004.06.033

Brandt A, Ellingsen KE, Brix S, Brokeland W, Malyutina M (2005) Southern ocean deep-sea isopod species richness (Crustacea, Malacostraca): influences of depth, latitude and longitude. Polar Biol 28:284-289. doi:10.1007/s00300-004-0688-Z

Brandt A, Brix S, Brokeland W, Choudhury M, Kaiser S, Malyutina M (2007) Deep-sea isopod biodiversity, abundance, and endemism in the Atlantic sector of the southern ocean-Results from the ANDEEP I-III expeditions. Deep-Sea Res Pt II 54:1760-1775. doi:10.1016/j.dsr2.2007.07.015

Braun M, Grossmann H (2002) Glacial changes in the areas of Admiralty Bay and Potter Cove, King George Island, maritime Antarctica. In: Beyer L, Bolter M (eds) Geoecology of the Antarctic ice-free coastal landscapes. Springer, Berlin, pp 75-90

Campos LS, Barboza CAM, Bassoi M, Bernardes M, Bromberg S, Corbisier TN, Fontes RF, Gheller PF, Hajdu E, Kawall HG, Lange PK, Lanna AM, Lavrado HP, Monteiro GCS, Montone RC, Morales T, Moura RB, Nakayama CR, Oackes T, Paranhos R, Passos FD, Petti MAV, Pellizari VH, Rezende CE, Rodrigues M, Rosa LH, Secchi E, Tenenbaum D, Yoneshigue-Valentin Y (2013) Environmental processes, biodiversity and changes in Admiralty Bay, King George Island, Antarctica. In: di Prisco G, Verde $\mathrm{C}$ (eds) Adaptation and evolution in marine environments, vol 2. Springer, Berlin, pp 127-156

Castello J (2004) Isopods (Crustacea, Isopoda) from the Spanish "Bentart-94/95" expeditions to the South Shetland Islands (subAntarctic). Polar Biol 28:1-14. doi:10.1007/s00300-004-0646-9

Catewicz Z, Kowalik Z (1983) Harmonic analysis of tides in Admiralty Bay. Oceanologia 15:97-109

Choudhury M, Brandt A (2009) Benthic isopods (Crustacea, Malacostraca) from the Ross Sea, Antarctica: species checklist and their zoogeography in the southern ocean. Polar Biol 32:599-610. doi:10.1007/s00300-008-0560-7

Clarke KR, Warwick RM (2001) Change in marine communities: an approach to statistical analysis and interpretation. Natural Environment Research Council, Plymouth

De Broyer C, Danis B, Allcock L, Angel M, Arango C, Artois T, Barnes D, Bartsch I, Bester M, Blachowiak-Samolyk K, Błażewicz M, Bohn J, Brandt A, Brandao SN, David B, de Salas M, Eleaume M, Emig C, Fautin D, George KH, Gillan D, Gooday A, Hopcroft R, Jangoux M, Janussen D, Koubbi P, Kouwenberg J, Kuklinski P, Ligowski R, Lindsay D, Linse K, Longshaw M, Lopez-Gonzalez P, Martin P, Munilla T,
Muhlenhardt-Siegel U, Neuhaus B, Norenburg J, Ozouf-Costaz C, Pakhomov E, Perrin W, Petryashov V, Pena-Cantero AL, Piatkowski U, Pierrot-Bults A, Rocka A, Saiz-Salinas J, SalviniPlawen L, Scarabino V, Schiaparelli S, Schrodl M, Schwabe E, Scott F, Siciński J, Siegel V, Smirnov I, Thatje S, Utevsky A, Vanreusel A, Wiencke C, Woehler E, Zdzitowiecki K, Zeidler W (2011) How many species in the Southern Ocean? Towards a dynamic inventory of the Antarctic marine species. Deep-Sea Res Pt II 58:5-17. doi:10.1016/j.dsr2.2010.10.007

DeBroyer C, Koubbi P (2014) The biogeography of the Southern Ocean. In: De Broyer C, Koubbi P, Griffiths HJ, Raymond B, d'Acoz Udekem C (eds) Biogeographic atlas of the Southern Ocean. Scientific Committee on Antarctic Research, Cambridge, pp 2-9

Hodgson T (1910) Crustacea. IX. Isopoda. National Antarctic expedition 1901-1904. Nat Hist 5:1-77

Ingels J, Vanreusel A, Brandt A, Catarino AI, David B, De Ridder C, Dubois P, Gooday AJ, Martin P, Pasotti F, Robert H (2012) Possible effects of global environmental changes on Antarctic benthos: a synthesis across five major taxa. Ecol Evol 2:453-485. doi:10.1002/ece3.96

Janecki T, Kidawa A, Potocka M (2010) The effects of temperature and salinity on vital biological functions of the Antarctic crustacean Serolis polita. Polar Biol 33:1013-1020. doi:10. 1007/s00300-010-0779-y

Jażdżewska A (2011) Soft bottom sublittoral amphipod fauna of Admiralty Bay, King George Island, Antarctic. Oceanol Hydrobiol Stud 40:1-10. doi:10.2478/s13545-011-0001-z

Jażdżewska AM, Siciński J (2017) Assemblages and habitat preferences of soft bottom Antarctic Amphipoda: Admiralty bay case study. Polar Biol. doi:10.1007/s00300-017-2107-2

Jażdżewski K, Teodorczyk W, Siciński J, Kontek B (1991) Amphipod crustaceans as an important component of zoobenthos of the shallow Antarctic sublittoral. Hydrobiologia 223:105-117

Kaiser S (2014) Antarctic and Sub-Antarctic isopod crustaceans (Peracarida, Malacostraca). In: De Broyer C, Koubbi P, Griffiths HJ, Raymond B, d'Acoz Udekem C (eds) Biogeographic atlas of the Southern Ocean. Scientific Committee on Antarctic Research, Cambridge, pp 166-172

Kaiser S, Barnes DKA, Brandt A (2007) Slope and deep-sea abundance across scales: southern ocean isopods show how the deep sea can be. Deep-Sea Res Pt II 54:1776-1789. doi:10.1016/ j.dsr2.2007.07.006

Kędra M, Gromisz S, Jaskuła R, Legeżynska J, Maciejewska B, Malec E, Opanowski A, Ostrowska K, Włodarska-Kowalczuk M, Węsławski JM (2010) Soft bottom macrofauna o the all taxa biodiversity site: Hornsund $\left(77^{\circ} \mathrm{N}\right.$, Svalbard). Pol Polar Res 31:309-326

Kędra M, Pabis K, Gromisz S, Węsławski M (2013) Distribution patterns of polychaete fauna in an Arctic fjord (Hornsund, Spitsbergen). Polar Biol 36:1463-1472. doi:10.1007/s00300013-1366-9

Kussakin OG (1967) Fauna od Isopoda and Tanaidacea in the coastal zones of the antarctic and subanatarctic waters. Issled Fauny Morei 4:220-380

Kussakin OG (1973) Peculiarities of the geographical and vertical distribution of marine isopods and the problem of deep sea fauna origin. Mar Biol 23:19-34

Lipski M (1987) Variations of physical conditions, nutrients and chlorophyll a contents in Admiralty Bay (King George Island, South Shetland Islands, 1979). Pol Polar Res 8:307-332

Longo G, Trovato M, Mazzei V, Ferrante M, Conti GO (2013) Ligia italica (Isopoda, Oniscidea) as bio indicator of mercury pollution of marine rocky coasts. PLoS ONE 8:e58548. doi:10.1371/ journal.pone.0058548

Lowry JK (1975) Soft bottom macrobenthic community of Arthur Harbor, Antarctica. Antarct Res Ser 23:1-19 
Magurran AE (2004) Measuring biological diversity. Blackwell Publishing, Malden

Marsz A (1983) From surveys of the geomorphology of the shores and bottom of the Ezcurra Inlet. Oceanologia 15:209-220

Moon HW, Rauhan WM, Hussin W, Kim HC, Ahn IY (2015) The impacts of climate change on Antarctic nearshore mega-epifaunal benthic assemblages in a glacial fjord on King George Island: responses and implications. Ecol Indi 57:280-292. doi:10.1016/j. ecolind.2015.04.031

Nonato EF, Brito TAS, Paiva PC, Petti MAV, Corbisier TN (2000) Benthic megafauna of the nearshore zone of Martel Inlet (King George Island, South Shetland Islands, Antarctica): depth zonation and underwater observations. Polar Biol 23:580-588. doi:10.1007/s003000000129

Nowak M, Kuklinski P, Siciński J (2014) Small-scale biomass variability of Antarctic bryozoans. Stud Trent Sci Nat 94:181-188

Pabis K, Błażewicz-Paszkowycz M (2011) Distribution and diversity of cumacean assemblages in Admiralty Bay, King George Island. Pol Polar Res 32:341-354. doi:10.2478/v10183-011-0024-6

Pabis K, Siciński J (2010a) Polychaete fauna associated with holdfasts of the large brown alga Himantothallus grandifolius in Admiralty Bay, King George Island, Antarctic. Polar Biol 33:1277-1288. doi:10.1007/s00300-010-0816-x

Pabis K, Siciński J (2010b) Distribution and diversity of polychaetes collected by trawling in Admiralty Bay-an Antarctic glacial fiord. Polar Biol 33:141-151. doi:10.1007/s00300-009-0692-4

Pabis K, Siciński J (2012) Is polychaete diversity in the deep sublittoral of an antarctic fjord related to habitat complexity? Pol Polar Res 33:181-197. doi:10.2478/v10183-012-0009-0

Pabis K, Sobczyk R (2015) Small scale spatial variation of soft bottom polychaete biomass in an Antarctic glacial fjord (Ezcurra Inlet, South Shetlands): comparison of sites at different levels of disturbance. Helgol Mar Res 69:113-121. doi:10.1007/s10152014-0420-5

Pabis K, Siciński J, Krymarys M (2011) Distribution patterns in the biomass of macrozoobenthic communities in Admiralty Bay (King George Island, South Shetlands, Antarctic). Polar Biol 34:489-500. doi:10.1007/s00300-010-0903-Z

Pabis K, Hara U, Presler P, Siciński J (2014) Structure of bryozoan communities in an Antarctic glacial fjord (Admiralty Bay, South Shetlands). Polar Biol 37:737-751. doi:10.1007/s00300-014-1474-1

Pabis K, Kędra M, Gromisz S (2015) Distinct or similar? Soft bottom polychaete diversity in Arctic and Antarctic glacial fjords. Hydrobiologia 742:279-294. doi:10.1007/s10750-014-1991-5

Pecherzewski K (1980) Distribution and quantity of suspended matter in Admiralty Bay (King George Island, South Shetland Islands. Pol Polar Res 1:75-82

Petti MAV, Nonato EF, Skowronski RSP, Corbisier TN (2006) Bathymetric distribution of the meiofaunal polychaetes in the nearshore zone of Martel Inlet, King George Island Antarctica. Antarct Sci 18:163-170. doi:10.1017/S0954102006000186

Piepenburg D, Archambault P, Ambrose WG Jr, Blanchard A, Bluhm B, Carroll CL, Conlan KE, Cusson M, Feder HM, Grebmeier JM, Jewett SC, Levesque M, Petryashev VV, Sejr MK, Sirenko BI, Wlodarska- Kowalczuk M (2011) Towards a pan-Arctic inventory of the species diversity of themacro- and megabenthic fauna of the Arctic shelf seas. Mar Biodiv 41:51-70. doi:10. 1007/s12526-010-0059-7

Poore GCB, Bruce NL (2012) Global diversity of marine isopods (except Asellota and crustacean symbionts). PLoS ONE 7:e43529. doi:10.1371/journal.pone.0043529

Presler P (1986) Necrophagous invertebrates of the Admiralty Bay of King George Island (South Shetland Islands, Antarctica). Pol Polar Res 7:25-61
Presler P, Figielska E (1997) New data on the Asteroidea of Admiralty Bay, King George Island, South Shetland Islands. Pol Polar Res 18:107-117

Pruszak Z (1980) Currents circulation in the water of Admiralty Bay (region of Arctowski Station on King George Island). Pol Polar Res 1:55-74

Richardson MD, Hedgpeth JW (1977) Antarctic soft-bottom, macrobenthic community adaptation to a cold, stable, highly productive, glacially affected environment. In: Llano GA (ed) Adaptation within Antarctic ecosystems. Proceedings of the Third SCAR Symposium on Antarctic Biology. Smithsonian Institution, Washington D.C., pp 181-196

Rudowski S, Marsz A (1996) Cechy rzeźby dna i pokrywy osadowe we współcześnie kształtujących się fiordach na przykładzie Hornsundu (Spitsbergen) i Zatoki Admiralicji (Antarktyka Zachodnia). Prace Wydziału Nawigacyjnego Wyższej Szkoły Morskiej w Gdyni 3:39-81

Sahade R, Lagger C, Torre L, Momo F, Monien P, Schloss I, Barnes DKA, Servetto N, Tarantelli S, Tatian M, Zamboni N, Abele D (2015) Climate change and glacier retreat drive shifts in an Antarctic benthic ecosystem. Sci Adv 1:e1500050. doi:10.1126/ sciadv. 1500050

Shepard FP (1954) Nomenclature based on salt-silt-clay ratios. J Sed Petrol 24:51-158

Siciński J (2004) Polychaetes of Antarctic sublittoral in the proglacial zone (King George Island, South Shetland Islands). Pol Polar Res 25:67-96

Siciński J, Jażdżewski K, DeBroyer C, Presler P, Ligowski R, Nonato EF, Corbisier TN, Petti MAV, Brito TAS, Lavrado HP, Błażewicz-Paszkowycz M, Pabis K, Jażdżewska A, Campos LS (2011) Admiralty bay benthos diversity-a census of a complex polar ecosystem. Deep-Sea Res Pt II 58:30-48. doi:10.1016/j.dsr2.2010.09.005

Siciński J, Pabis K, Jażdżewski K, Konopacka A, BłażewiczPaszkowycz M (2012) Macrozoobenthos of two Antarctic glacial coves: a comparison with non-disturbed bottom areas. Polar Biol 35:355-367. doi:10.1007/s00300-011-1081-3

Szafranski J, Lipski M (1982) Characteristic of water temperature and salinity at admiralty bay (King George Island) during austral summer 1978-1979. Pol Polar Res 3:7-24

Teodorczyk W, Wagele JW (1994) On Antarctic species of genus Munna, Kroyer 1839 (Crustacea, Isopoda, Asellota, Munnidae). Bull Mus Nat His Nat 16:111-201

Tokarczyk R (1986) Annual cycle of chlorophyll a in Admiralty Bay 1981-1982 (King George Island, South Shetland). Pol Arch Hydrobiol 3:177-188

Tokarczyk R (1987) Classification of water masses in the Bransfield Strait and southern part of the Drake Passage using a method of statistical multidimensional analysis. Pol Polar Res 8:333-366

Veloso VG, Neves G, de Almeida Capper L (2011) Sensitivity of a cirolanid isopod to human pressure. Ecol Indi 11:782-788. doi:10.1016/j.ecolind.2010.10.004

Walsh JE (2009) A comparison of Arctic and Antarctic climate change, present and future. Antarct Sci 21:179-188. doi:10. 1017/S0954102009001874

Węsławski JM, Kendall MA, Włodarska-Kowalczuk M, Iken K, Kędra M, Legeżynska J, Sejr MK (2011) Climate change effects on Arctic fjord and coastal macrobenthic diversity-observations and predictions. Mar Biodiv 41:71-85. doi:10.1007/ s12526-010-0073-9

Włodarska-Kowalczuk M, Pearson T (2004) Soft-bottom macrobenthic faunal associations and factors affecting species distributions in an Arctic glacial fjord (Kongsfjord, Spitsbergen). Polar Biol 27:155-167. doi:10.1007/s00300-003-0568-y 
Young JS, Peck LS, Matheson T (2006) The effects of temperature on walking and righting in temperate and Antarctic crustaceans. Polar Biol 29:978-987. doi:10.1007/s00300-006-0140-7

Zemko K, Brix S (2011) New species of desmosomatid isopods from Admiralty Bay, King George Island. Pol Polar Res 32:321-340. doi: 10.2478/v10183-011-0022-8

Zemko K, Kaiser S (2012) Thambema thunderstruckae sp. n., the first record of Thambematidae (Isopoda: Asellota) from the Southern
Hemisphere shelf. Pol Polar Res 33:163-179. doi:10.2478/ v10183-012-0008-1

Zemko K, Pabis K, Siciński J, Błażewicz-Paszkowycz M (2015) Diversity and abundance of isopod fauna associated with holdfasts of the brown alga Himantothallus grandifolius in Admiralty Bay, Antarctic. Pol Polar Res 36:405-415. doi:10. 1515/popore-2015-0023 